UDC 541.13.544.65

\title{
MATHEMATICAL MODELING THE ELECTROCHEMICAL DEPOSITION PROCESS OF Ni-Mo THIN FILMS
}

\author{
U.M.Gurbanova, Z.S.Safaraliyeva, N.R.Abishova, R.G.Huseynova, D.B.Tagiyev \\ M.Nagiyev Institute of Catalysis and Inorganic Chemistry, NAS of Azerbaijan \\ uqurbanova92@gmail.com
}

Received 03.03.2021

Accepted 19.05.2021

\begin{abstract}
To avoid the numerous experiments for determining optimal conditions and electrolyte composition at co-deposition of two metals we have cleated the regression equation. Mathematical calculations have been carried out using the Optum ME package program with the study of some factors as current density, concentration of main components, temperature, etc. which effect on the co-deposition process. Three independent variables have been selected. The amount of molybdenum in the deposit has been chosen as the dependent variable. The developed regression equation quite adequately describes the codeposition process of nickel with molybdenum and can be used at planning the works on obtaining alloys with the required composition by the electrochemical method.
\end{abstract}

Keywords: mathematical model, nickel, molybdenum, thin films, electrodeposition.

doi

\section{Introduction}

It is known that hydrogen in free form exists in small quantities, but it can be obtained from an available resource - water, which is practically inexhaustible on earth. The usual method of obtaining hydrogen is the electrolysis process of water, as a result of this water decomposes into its constituent parts - hydrogen and oxygen. This process practically does not cause environmental pollution and therefore the production of hydrogen by electrolysis of water has a great future, considering that the only chemical substance in this case is water. But the limiting factor for the large-scale use of electrolytic splitting of water is the high consumption of energy during electrolysis [1-5]. It is well known that the most active materials for the hydrogen evolution reaction (HER) are noble metals such as platinum, gold, silver, palladium and ruthenium [6-10], but their high cost limits their use in hydrogen production. Nickel possesses electrocatalytic properties, is often used as a cathode in industry; however, a high value of hydrogen overvoltage at this electrode increases energy consumption $[11,12]$. It is well known that doping Ni by transition metals (Mo, W) increases its electrocatalytic activity for the HER reaction [13-16]. The production of thin layers of nickel-based alloys of high catalytic activity is very important for the water electrolysis process. Some factors, such as electrolyte composition, current density, concentration of main components, temperature, additives, etc., affect the process of obtaining thin Ni-Mo films by electrochemical deposition. It is rather difficult to establish the effect of each factor on the process, since during the experiments one of the parameters changes, while the other parameters of the process remain unchanged. This makes it difficult to choose the optimal conditions. Such method is quite long acting and laborious and sometimes it even makes it difficult to determine the optimal conditions. Therefore, the method of planning an experiment is of considerable interest in the optimization of multifactorial problems and allows us to construct a mathematical model that connects the optimization parameter with the factors influencing its value.

\section{Experimental methods}

When constructing the mathematical model of the Ni-Mo electrodeposition process, we used the experimental data obtained as a result of the studies $[15,16]$. The regression equation has been created on the basis of the obtained data; the criteria of significance and adequacy have been calculated [17-19] to confirm 
the results of the experiment. All possible combinations have been calculated for the selected levels when planning the process through a complex scheme of experiments. All mathematical calculations have been carried out using the Optum ME package program. The number of required experiments has been calculated using the following formula: $N=2^{k}$, where, $k$ is the number of factors affecting the co-deposition process.

\section{Results and discussion}

In electroplating (galvanotechnology), the obtaining alloys of a given composition is accompanied with a number of difficulties relatıng to the influence of various factors on the process, at times acting in opposite directions, and it is sometimes rather difficult to take into account the influence of each factor. Three main factors effect on the co-deposition process of nickel with molybdenum: the concentration of $\mathrm{Na}_{2} \mathrm{MoO}_{4} \times 2 \mathrm{H}_{2} \mathrm{O}$ $\left(\mathrm{Z}_{1}\right)$, which varied within $(0.03 \div 0.13) \mathrm{M}$, the concentration of $\mathrm{NiSO}_{4} \cdot 7 \mathrm{H}_{2} \mathrm{O}\left(\mathrm{Z}_{2}\right)$, which varied within $(0.02 \div 0.124) \mathrm{M}$, and the current density $\left(Z_{3}\right)(0.5 \div 2.5) \mathrm{A} / \mathrm{dm}^{2}$. The objective function of optimization is the amount of molybdenum in deposits $(y)$ (Mo, mass \%).

All factors of the full factorial experiment have been varied at two levels - maximum (+1) and minimum $(-1)$ - for the convenience to calculate the regression coefficients.

The preliminary experiments have been carried out before the start of optimization and the values of the factors at which the best result was obtained have been taken as the main level. We choose a variation interval and form a planning matrix, in which the factors effecting on the electrodeposition process are included in a coded value $(+1$ or -1$)$.

The possible number of combinations for processes with three independent factors is equal to $N=2^{3}=8$. The conditions of the experiments, the planning matrix and the results of the experiments are shown in the Table. Preliminary experiments made it possible to choose the variation interval so that the values of the optimization parameter were in the range of 3080 mass $\%$ of molybdenum.
Experiment planning matrix

\begin{tabular}{|c|c|c|c|c|c|c|c|}
\hline \multirow{2}{*}{$\begin{array}{c}\text { Expe- } \\
\text { riment } \\
\text { No }\end{array}$} & \multicolumn{2}{|c|}{ Natural factors of scale } & \multicolumn{2}{|c|}{ Scale factors } & \multirow{2}{*}{$y$} \\
\cline { 2 - 7 } & $Z_{1}$ & $Z_{2}$ & $Z_{3}$ & $x_{1}$ & $x_{2}$ & $x_{3}$ & \\
\hline 1 & 0.03 & 0.02 & 0.5 & -1 & -1 & -1 & 54 \\
\hline 2 & 0.03 & 0.02 & 2.5 & -1 & -1 & +1 & 71 \\
\hline 3 & 0.03 & 0.124 & 0.5 & -1 & +1 & -1 & 30 \\
\hline 4 & 0.03 & 0.124 & 2.5 & -1 & +1 & +1 & 45 \\
\hline 5 & 0.13 & 0.02 & 0.5 & +1 & -1 & -1 & 48 \\
\hline 6 & 0.13 & 0.02 & 2.5 & +1 & -1 & +1 & 63 \\
\hline 7 & 0.13 & 0.124 & 0.5 & +1 & +1 & -1 & 73 \\
\hline 8 & 0.13 & 0.124 & 2.5 & +1 & +1 & +1 & 80 \\
\hline
\end{tabular}

Using formulas (1):

$$
\begin{aligned}
& Z_{j}^{0}=\frac{Z_{j}^{\max }+Z_{j}^{\min }}{2}, \Delta Z_{j}=\frac{Z_{j}^{\max }-Z_{j}^{\min }}{2}, \\
& j=1,2,3 .
\end{aligned}
$$

the values of $Z$ have been calculated for all factors effecting on the process:

$Z_{1}^{0}=\frac{0.03+0.13}{2}=0.08, \Delta Z_{1}=\frac{0.13-0.03}{2}=0.05$, $Z_{2}^{0}=0.077, \Delta Z_{2}=0.052, Z_{3}^{0}=1.5, \Delta Z_{3}=1$.

In regression equations all independent variables are included in the equation as a coded value, however they are related to natural parameters by the following formula:

$$
x_{j}=\frac{Z_{j}-Z_{j}^{0}}{\Delta Z_{j}}, \quad j=1,2,3 .
$$

For example:

at $Z_{1}=0.03$, the value of $x_{1}=\frac{0.03-0.08}{0.05}=-1$.

The coefficients of the regression equation are determined by the method of least squares as follows: any coefficient of the regression equation $b_{j}$ is equal to scalar multiplication of the column $y$ by the value $x_{j}$ and the result is divided into a number of experiments in the planning matrix, in this case is 8 :

$$
b_{j}=\frac{1}{8} \sum_{i=1}^{8} x_{j i} y_{i} \text {. }
$$

In the table the coefficients of linear regression equation are calculated first:

$$
\hat{y}=b_{0}+b_{1} x_{1}+b_{2} x_{2}+b_{3} x_{3}
$$


Let's calculate the value of one of coefficients for example:

$$
\sum_{i=1}^{8} x_{1 i} y_{i}=64, b_{1}=\frac{\sum_{i=1}^{8} x_{1 i} y_{i}}{8}=\frac{64}{8}=8 \text {. }
$$

The values of the other coefficients have been calculated in this way:

$$
b_{0}=58 ; b_{2}=-1 ; b_{3}=6.75 \text {. }
$$

By inserting the values of these coefficients into the regression equation, we get the following expression:

$$
y=58+8 x_{1}-x_{2}+6.75 x_{3} .
$$

The optimization parameter of a threecomponent system is determined by the BoxWilson equation using the following expression [20]:

$$
\begin{aligned}
& \hat{y}=b_{0}+b_{1} x_{1}+b_{2} x_{2}+b_{3} x_{3}+b_{12} x_{1} x_{2}+b_{13} x_{1} x_{3}+ \\
& +b_{23} x_{2} x_{3}+b_{123} x_{1} x_{2} x_{3} .
\end{aligned}
$$

Then the coefficients of the relationship between parameters of the process have been determined. So, to calculate the coefficient $b_{12}$ it is necessary to perform the following calculations:

$$
b_{12}=\frac{\sum_{i=1}^{8}\left(x_{1} x_{2}\right)_{i} y_{i}}{8}=-11.5 .
$$

Other coefficients are determined in the same way:

$$
b_{13}=-1.25, b_{23}=-1.25, b_{123}=-0.75 \text {. }
$$

Some regression coefficients can be insignificant. Their significance is determined using the Student's $t$-criterion (Student's $t$-test) according to the formula:

$$
t_{0}=b_{0} / S_{b 0}
$$

Student's and Fisher's criteria, and also the regression coefficients have been determined, and the adequacy of the equation has been checked currying out additional parallel experiments. Due to the fact that the covariance matrix of experiments design $\left(X^{T} X\right)^{-1}$ is a diagonal matrix, the coefficients of the regression model were not correlated with each other. The each coefficient values of the regression equation have been separately tested using the Student's test. Insignificant coefficients have been excluded from the regression equation that does not affect the value of other coefficients. In other words, the values of the coefficients of the regression equation characterize the effect of the corresponding factor on the value of $y$. The diagonal elements of the covariance matrix are equal to each other, so all the coefficients of equations (3) and (4) have been determined with the same accuracy: $S_{b j}=S / \sqrt{\mathrm{N}}$.

After that, three additional parallel experiments have been carried out under conditions corresponding to the planning center in the table and the following values of $y$ have been obtained:

$$
\begin{gathered}
y_{1}^{0}=48.7 ; y_{2}^{0}=48.3 ; y_{3}^{0}=48.9 . \\
\bar{y}^{0}=\frac{\sum_{n=1}^{3} y_{n}^{0}}{3}=48.63, \\
S^{2}=\frac{\sum_{n=1}^{3}\left(y_{n}^{0}-\bar{y}^{0}\right)^{2}}{3}=\frac{0.0044+0.111+0.071}{3}=0.062, \\
S=\sqrt{0.062}=0.25, \\
S_{b j}=0.25 / \sqrt{8}=0.089 .
\end{gathered}
$$

Calculated coefficient with reference to the Student's $t$ test are:

$$
t_{0}=\frac{\left|b_{0}\right|}{S_{b o}}=\frac{58}{0.089} \approx 651.6 .
$$

Here, $S_{b 0}$ - root-mean-square deviation of the experiment (RMSD), $\left|b_{0}\right|$ - the coefficient of regression.

The value of the Student's criterion for the number of degrees of freedom $f=2$ and the significance level $P=0.05$ is equal to $t_{p}(f)=4.3$. In our case, all the calculated coefficients, except of coefficient the $b_{12}$, were significant according to the Student's criterion. And the regression equation takes the following form: 
$\hat{y}=58+8 x_{1}-x_{2}+6.75 x_{3}-11.5 x_{1} x_{2}-1.25 x_{1} x_{3}-$ $-1.25 x_{2} x_{3}$.

The valuation of the adequacy of the obtained equation has been carried out according to the Fisher criterion, and the transition from a dimensionless scale to a natural size has been carried out using formula (2), as a result of that the following equation was obtained:

$$
\begin{aligned}
& \hat{y}=58.1-143.1 Z_{1}-337 Z_{2}+10.6 Z_{3}+4423 Z_{1} Z_{2}- \\
& -25 Z_{1} Z_{3}-24 Z_{2} Z_{3} .
\end{aligned}
$$

Adequacy of obtained equation (5) has been determined in conformity with the following formula:

$$
\varepsilon=\frac{\sum\left(\frac{C^{\exp }-C^{c a l}}{C^{\exp }}\right)^{2}}{8} \cdot 100 \%
$$

As a result of calculations the error of formula (7) was established, $\varepsilon=2.85 \%$.

In the range of the investigated values of technological parameters, the maximum yield of the final product is $80 \%$.

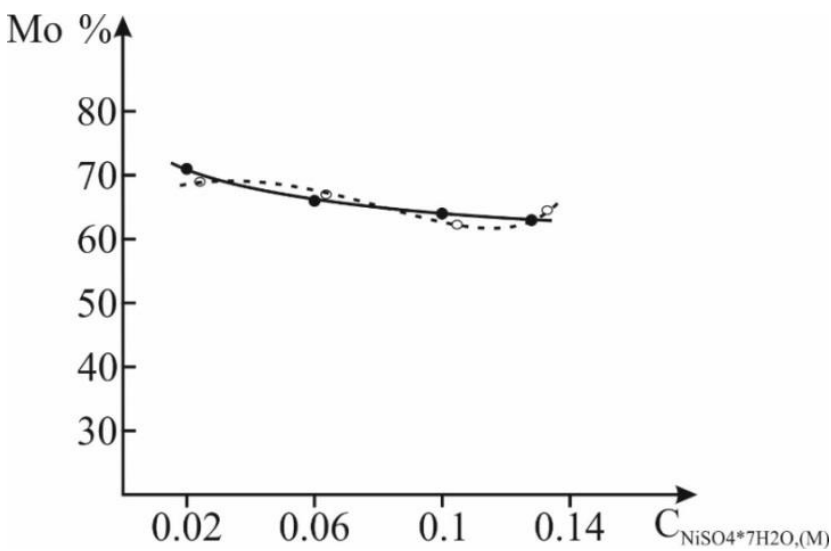

Fig. 1. Dependence of the molybdenum content in deposits on the concentration of $\mathrm{NiSO}_{4} \cdot 7 \mathrm{H}_{2} \mathrm{O}$ in the electrolyte. Solid lines are calculated data, dashed lines are experimental values. Electrolyte composition (M): $0.124 \mathrm{Na}_{2} \mathrm{MoO}_{4} \cdot 2 \mathrm{H}_{2} \mathrm{O} ; 0.1 \mathrm{H}_{3} \mathrm{BO}_{3} ; 0.13$ $\mathrm{NiCl}_{2} \cdot 6 \mathrm{H}_{2} \mathrm{O} ; 7 \mathrm{NH}_{4} \mathrm{OH} ; \mathrm{i}_{\mathrm{c}}=1.0 \mathrm{~A} / \mathrm{dm}^{2}, \mathrm{pH}=11.2$, $T=293 \mathrm{~K}$.
It can be concluded that the mathematical modeling of the function $y$ (molybdenum content in the alloy Mo, mass\%) that is the object of optimization has been devised and technological conditions that ensure the maximum values of the function $y$ have been determined on the basis of equation (7) and taking into account the limitation of factors. Consequently, the interval of research of technological parameters $Z_{1}=0.13, Z_{2}=0.124$ and $Z_{3}=2.5$ provides the maximum yield of the main product $y_{\text {max }}=80 \%$.

To check the fact that the elaborated mathematical model enough accurately describes the process of co-deposition of nickel with molybdenum, experiments have been carried out with arbitrarily chosen parameters. Figures 1, 2 and 3 show the dependences of the alloy composition on the concentration of nickel (Figure 1), on the concentration of molybdenum (Figure 2) and on the current density (Figure 3) obtained experimentally and from calculation.

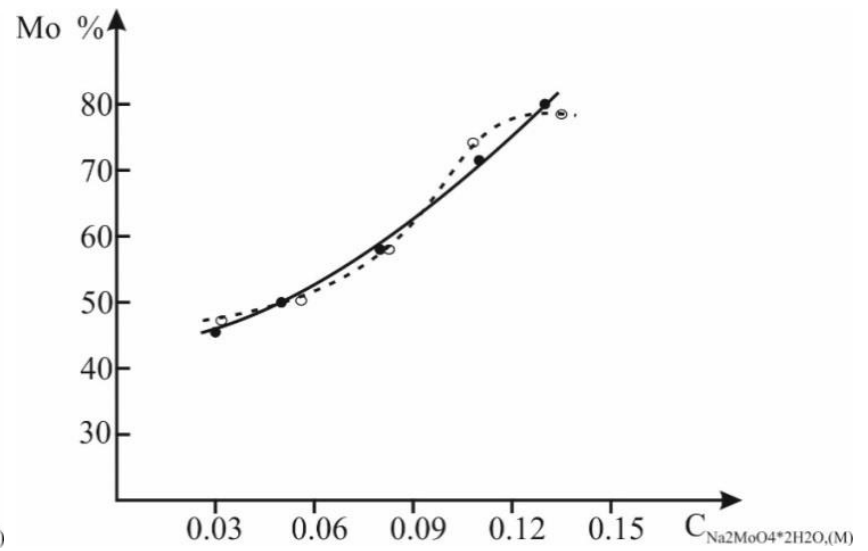

Fig. 2. Dependence of the molybdenum content in deposits on the concentration of $\mathrm{Na}_{2} \mathrm{MoO}_{4} \cdot 2 \mathrm{H}_{2} \mathrm{O}$ in the electrolyte. Solid lines are calculated data, dashed lines are experimental values. Electrolyte composition (M): $0.107 \mathrm{NiSO}_{4} \cdot 7 \mathrm{H}_{2} \mathrm{O} ; 0.1 \mathrm{H}_{3} \mathrm{BO}_{3}$; $0.13 \mathrm{NiCl}_{2} \cdot 6 \mathrm{H}_{2} \mathrm{O} ; 7 \mathrm{NH}_{4} \mathrm{OH} ; \mathrm{i}_{\mathrm{c}}=2.5 \mathrm{~A} / \mathrm{dm}^{2}, \mathrm{pH}=$ $11.2, T=293 \mathrm{~K}$. 


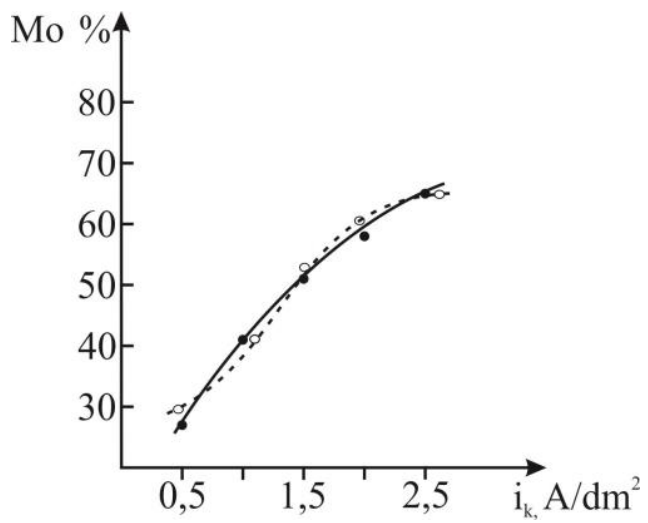

Solid lines correspond to calculated data obtained from equation (4), and dashed lines to experimental data. Comparison of the calculated data with the results obtained experimentally proves that the co-deposition process is quite accurately described by equation (4).

The obtained regression equation makes it possible to calculate the amount of molybdenum in an electrolytic Ni-Mo alloy at a given concentration of alloy components and quite accurately describes the electrodeposition process of nickel with molybdenum, determining the relationship of the alloy composition with the electrolyte composition and the parameters of electrolysis.

\section{Conclusions}

The regression equation that quite adequately describes the process of co-deposition of nickel with molybdenum has been obtained as a result of calculations carried out on the basis of the obtained experimental data. Taking into account the fact that $\mathrm{Ni}-\mathrm{Mo}$ alloys form a continuous series of solid solutions that are widely used in practice, this equation can be used in planning work on obtaining alloys with required composition by the electrochemical method. The regression equation shows that the ratio of the concentrations of the main components in the electrolyte has the greatest effect on the composition of the deposited films.

\section{References}

1. Rashid M., Mesfer M.K.A., Naseem H., Danish M. Hydrogen production by water electrolysis: a review of alkaline water electrolysis, PEM water electrolysis and high temperature water elec-
Fig. 3. Dependence of the molybdenum content on the current density. Solid lines are calculated data, dashed lines are experimental values. Electrolyte composition (M): $0.107 \quad \mathrm{NiSO}_{4} \cdot 7 \mathrm{H}_{2} \mathrm{O} ; 0.124$ $\mathrm{Na}_{2} \mathrm{MoO}_{4} \cdot 2 \mathrm{H}_{2} \mathrm{O} ; 0.1 \quad \mathrm{H}_{3} \mathrm{BO}_{3} ; 0.13 \quad \mathrm{NiCl}_{2} \cdot 6 \mathrm{H}_{2} \mathrm{O}$; $7 \mathrm{NH}_{4} \mathrm{OH} ; \mathrm{pH}=11.2, T=293 \mathrm{~K}$.

trolysis. In. J. Eng. Advanced Technology. 2015. V. 4. № 3. P. 80-93. (IJEAT) ISSN: 2249-8958.

2. Bayeshova A.K., Molaigan S., Bayeshov A.B. Hydrogen energetics current state and hydrogen production methods. News of the National Academy of sci. republic of Kazakhstan. Ser. chem. technology. 2018. V. 5. № 431. P. 107-116.

3. Aliyev A.Sh., Guseynova R.G., Gurbanova U.M., Babanly D.M., Fateev V.N., Pushkareva J.V., Tagiyev D.B. Electrocatalysts for water electrolysis. J. Chemical Problems. 2018. V. 16. № 3. P. 283-306.

4. Kryukov Yu., Lukovtsev V.P., Petrenko E.M., Khozyainova N.S. Electrochemical cathode active platinum and platinum-palladium electrocatalysts for alkaline water electrolysis. Electrochem. Energy. 2012. V. 12. № 1. P. 36-38.

5. Safizadeh F., Ghali E., Houlachi G. Electrocatalysis developments for hydrogen evolution reaction in alkaline solutions. A Review. Int. J. Hydrogen Energy. 2015. V. 40. № 1. P. 256-274.

6. Lima F.H.B., Calegaro M.L., Ticianelli E.A. Electrocatalytic activity of dispersed platinum and silver alloys and manganese oxides for the oxygen reduction in alkaline electrolyte. Russ. J. Electrochem. 2006. V. 42. № 12. P. 1283-1290.

7. Savadogo O., Ndzebet E. Influence of $\mathrm{SiW}_{12} \mathrm{O}_{40}{ }^{4-}$ on the electrocatalytic behaviour of $\mathrm{Pt}-\mathrm{Co}$ alloy supported on carbon for water electrolysis in $3 \mathrm{M}$ $\mathrm{KOH}$ aqueous solution. Int. J. Hydrogen Energy. 2001. V. 26. № 3. P. 213-218.

8. Santos D.M.F., Sequeira C.A.C., Macciò D., Saccone A., Figueiredo J.L. Platinum-rare earth electrodes for hydrogen evolution in alkaline water electrolysis. Int. J. Hydrogen Energy. 2013. V. 38. № 8. P. 3137-3145.

9. Stojić D.Lj., Grozdić T.D., Kaninski M.P.M., Stanić V.D. Electrocatalytic effects of Mo-Pt intermetallics singly and with ionic activators. Hydrogen production via electrolysis. Int. J. Hydrogen Energy. 2007. V. 32. № 13. P. 2314-2319.

10. González-Buch C., Herraiz-Cardona I., Ortega E.M., Mestre S., Pérez-Herranz V. Synthesis and characterization of Au-modified macroporous Ni electro- 
catalysts foralkaline water electrolysis. Int. J. Hydrogen Energy. 2016. V. 41. № 2. P. 764-772.

11. Kim S.M., Jin S.H., Lee Y.J., Lee M.H., Design of nickel electrodes by electrodeposition: effect of internal stress on hydrogen evolution reaction in alkaline solutions. Electrochim Acta. 2017. V. 252. P. 67-75.

12. Zhu Y., Liu T., Li L., Song S., Ding R. Nickelbased electrodes as catalysts for hydrogen evolution reaction in alkaline media. Ionics. 2017. V. 24. № 4. P. 1121-1127.

13. Yahia H.A., Mohamed A.M.A., Golden T.D., D'Souza N., Electrodeposition of nanocrystalline Ni-Mo alloys from alkaline glycinate solutions. Int. J. Electrochem. Sci. 2014. V. 9. P. 6438-6450.

14. Beltowska-Lehman E., Indyka P. Kinetics of Ni-Mo electrodeposition from Ni-rich citrate baths. Thin Solid Films. 2012. V. 520. № 6. P. 2046-2051.

15. Ivanova N.A., Spasov D.D., Kurbanova U.M., Guseinova R.G., Aliev A.Sh. Electrochemical synthesis of Ni-Mo-based nanocatalysts for the hy- drogen evolution reaction. Sixth All-Russia. conf. from international participation. $\square$ Fuel cells and power plants based on them $\square$. Moscow. June 2327, 2019, pp. 277-279.

16. Gurbanova U.M., Huseynova R.G., Tahirli H.M., Dadashova S.D., Aliyev A.Sh., Tagiyev D.B. Electrodeposition of Ni-Mo alloys from ammonium electrolytes. Azerb. Chem. J. 2019. № 3. P. 25-31.

17. Samara A.A. Introduction to numerical methods. M.: Lan, 2005. P. 288.

18. Bykov V.I., Zhuravlev V.M. Modeling and optimization of chemical-technological processes. Krasnoyarsk: CPI KSTU. 2002. P. 298.

19. Akhnazarova S.L., Kafarov V.V. Methods of experiment optimization in chemical technology. M.: Higher School. 1985. P. 327.

20. Kafarov V.V. Cybernetics Methods in Chemistry and Chemical Technology. L .: Chemistry, 1971. P. 190.

\section{Ni-Mo NAZIKK TəBəQӘLəRININ ELEKTROKIMYəVI YOLLA ÇÖKDÜRÜLMəSI PROSESININ RIYYAZI MODELLOŞDİRILMəSI}

\section{Ü.M.Qurbanova, Z.S.Səfərəliyeva, N.R.Abışova, R.Q.Hüseynova, D.B.Tağıyev}

Bütün riyazi hesablamalar cərəyan sıxlığı, əsas komponentlərin qatılığı, temperatur və s. kimi çökmə prosesinə təsir edən amillərin öyrənilməsi ilə Optum ME proqram paketindən istifadə etməklə həyata keçirilmişdir. İki metalın birgə çökməsi zamanı optimal elektroliz şəraiti və elektrolitin tərkibini çoxsaylı təcrübələr aparmaqla müəyyən etmək olar. Lakin reqressiya tənliyindən istifadə etməklə, prosesin riyazi modelini quraraq bunun qarşısını almaq olar. Reqressiya tənliyini qurarkən üç asılı olmayan dəyişən seçilmişdir. Çöküntüdə molibdenin miqdarı asılı olmayan dəyişən kimi seçilmişdir. Đldə edilmiş reqressiya tənliyi nikelin molibden ilə birgə çökmə prosesini bütövlükdə ifadə edir və elektrokimyəvi üsulla tələb olunan tərkibdə ərintilərin istehsalı zamanı işlərin planlaşdırılmasında istifadə edilə bilər.

Açar sözlər: riyazi modellaşmə, nikel, molibden, nazik təbəqalar, elektroçökdürülmə.

\section{МАТЕМАТИЧЕСКОЕ МОДЕЛИРОВАНИЕ ПРОЦЕССА ЭЛЕКТРОХИМИЧЕСКОГО ОСАЖДЕНИЯ ТОНКИХ ПЛЕНОК Ni-Mo}

\section{У.М.Курбанова, З.С.Сафаралиева, Н.Р.Абышова, Р.Г.Гусейнова, Д.Б.Тагиев}

Во избежание многочисленных экспериментов для определения оптимальных условий и состава электрорлита при соосаждении двух металлов мы разработали регрессионное уравнение. Математические расчеты проведены с помощью пакетной программы Optum ME c исследованием таких факторов, влияющих на процесс совместного осаждения, как плотность тока, концентрация основных компонентов, температура и т.д. Были выбраны три независимые переменные. В качестве зависимой переменной выбрано содержание молибдена в осадке. Разработанное уравнение регрессии вполне адекватно описывает процесс совместного осаждения никеля с молибденом и может быть использовано при планировании работ по получению электрохимическим методом сплавов требуемого состава.

Ключевые слова: математическая модель, никель, молибден, тонкие пленки, электроосаждение. 